open en diepgaande dialogen, maar onderzoek laat zien dat professionals via de keukentafel het privédomein van zorgbehoeftige mensen betreden. Vanuit een ongelijke machtsverdeling tussen professional en hulpbehoevende cliënt wordt er vervolgens onderhandeld over de mate van zelfstandigheid [1]. Zelfstandigheid en inherent daaraan de kwaliteit van leven zijn verworden tot een onderhandelingskwestie. Kwetsbare groepen worden eveneens onvoldoende gehoord, net zoals mensen met een chronische aandoening. Onder beide groepen valt nog een (leef)wereld te winnen. Gemeenten lijken vooralsnog niet goed in staat om het échte leven te doorgronden. Ook ervaringsdeskundigen hebben het moeilijk. Gemotiveerd als ze zijn, worden ze nog te vaak voor een habbekrats ingezet. In de verantwoordingsdruk van lokale overheden moeten ze voldoen aan de eisen die gesteld worden aan professionele hulpverleners. Daarmee verliezen ze hun authenticiteit, hun echtheid. Ervaringsdeskundigen zijn er bij de gratie van hun ervaring. Door die ervaring kunnen ze het échte leven van de hulpbehoevende cliënt goed invoelen en gericht persoonlijk advies geven over zelfstandigheid, eigen kracht en eigen regie. Bureaucratisering en organisatie-inbedding (met eisen ten aanzien van vakbekwaamheid en training) dwingen hen tot een geprotocolleerde werkwijze, waarmee we het paard achter de wagen spannen.

Jaarlijks komen er pakweg duizend nieuwe woorden bij en schrijft Van Dale een prijsvraag uit voor het leukste, mooiste nieuwe publiekswoord. Hét woord van het jaar wordt dan bekendgemaakt. Het lijkt niet aannemelijk dat de term 'sociaal domein' ooit in de prijzen zal vallen. Tenzij er een echte verbinding ontstaat tussen het woord en het dagelijkse leven van miljoenen inwoners in Nederland.

\section{Literatuur}

1. Hees S van, Horstman K, Jansen MWJ, et al. How does an ageing policy translate into professional practices? An analysis of kitchen table conversations in the Netherlands. Eur J Soc Work. https://doi.org/10.1080/13691457.2018. 1499610. [epub] 17 Jul 2018.

\title{
Aansluiten bij de paradigmashift: de betrokkenheid van inwoners bij beleid
}

\author{
Karin Verbeek $\cdot$ Kees-Jan van de Werfhorst
}

Published online: 7 November 2018

(C) Bohn Stafleu van Loghum is een imprint van Springer Media B.V., onderdeel van Springer Nature 2018

Gemeenten hebben de opdracht om inwoners te betrekken bij de Wmo 2015. Dit blijft in veel gemeenten echter beperkt tot vertegenwoordiging door adviesraden, waarin kwetsbare inwoners nauwelijks of indi-

Dit artikel is een bewerking van een artikel dat eerder is verschenen op www.sociaalweb.nl. Martijn Kole is ervaringsdeskundige en oprichter van Herstelacademie Enik in Utrecht. Vanessa Duterloo is beleidsadviseur Maatschappelijke Ontwikkeling in de gemeente Oss. Jet van den Biggelaar was tot 1 mei actief als beleidsadviseur Sociaal Domein in de gemeente Almere.

K. Verbeek $(\triangle) \cdot$ K.-J. van de Werfhorst BMC Advies, Den Haag, Nederland

karin.verbeek@bmc.nl rect vertegenwoordigd worden. Zo sluiten gemeenten onbedoeld inwoners uit van beleidsparticipatie. Laagdrempelige vormen van inspraak bieden beleidsmakers kansen. Dit vraagt in gemeentelijke organisaties op alle niveaus om een verandering in houding en gedrag.

\section{De adviesraad als belangrijkste vorm voor beïnvloeding}

De verhouding tussen inwoners en overheid is aan het veranderen. De overheid ontwikkelt zich van bepalend en beslissend, naar een speler met een faciliterende rol [1]. De inwoner met zijn individuele mogelijkheden staat centraal en vindt waar nodig ondersteuning in de samenleving en bij de overheid. Ook 
wat betreft het beleidsproces heeft dit in de Wmo 2015 een prominente plek gekregen: 'Inwoners in het algemeen, cliënten of hun vertegenwoordigers moeten "adequaat" kunnen deelnemen aan het beleidsproces. Gemeente en aanbieders hebben de verantwoordelijkheid om hiervoor de voorwaarden te scheppen'. De vorm hiervoor staat vrij.

Uit ons onderzoek Beleidsparticipatie in de Wmo 2015 blijkt dat gemeenten de beleidsparticipatie van inwoners een impuls willen geven [2]. Veel gemeenten hebben na 2015 echter vastgehouden aan de adviesraden als belangrijkste beïnvloedingskanaal voor inwoners.

\section{Te weinig invloed van kwetsbare groepen}

Adviesraden sluiten sommige kwetsbare inwoners onbedoeld uit. Niet iedereen durft immers in het openbaar te spreken. Of de angst om eigen emoties niet in de hand te hebben is een belemmerende factor. Ook weten adviesraden maar moeilijk verbinding te leggen met bepaalde doelgroepen. Ons onderzoek laat zien dat kwetsbare inwoners daarom voornamelijk indirect vertegenwoordigd worden in gemeentelijke beleidsprocessen. Zorgprofessionals of betrokken burgers zonder ervaringskennis spreken namens de meest kwetsbare inwoners. Mensen in een kwetsbare situatie zelf hebben daardoor nog maar weinig invloed op gemeentelijk beleid.

Deelnemer aan het onderzoek en ervaringsdeskundige Martijn Kole legt uit: 'We willen nu te graag dat de burger in de systeemwereld past, maar dat gaat niet gebeuren. Er is te veel losgeknipt uit de sociale context; beleidsmakers draaien daar niet in mee. Zij zien inwoners dan te vaak als homogene groep'.

\section{Recht doen aan verschillen}

Om bij beleidsvorming recht te doen aan de diversiteit van inwoners, is ook variëteit nodig in samenwerkingsvormen voor beleidsmakers, bestuurders en inwoners. Belangenbehartiging, advisering, ervaringskennis en ervaringsdeskundigheid hebben allemaal hun eigen waarde. Gemeenten experimenteren steeds vaker met nieuwe samenwerkingsvormen, zo zien we in het onderzoek. De proeftuin Ruwaard in de gemeente Oss is zo'n voorbeeld.

Vanessa Duterloo: 'In Ruwaard doen we per individu en per onderwerp wat nodig is. We - gemeente, inwoners en organisaties - zijn samen verantwoordelijk voor het eindresultaat, binnen afgesproken kaders. En alles wat er dan gebeurt, tussen professionals en inwoners, tussen professionals onderling, tussen organisaties en de gemeente, geeft ons inzicht in hoe we het achter de schermen moeten organiseren. Dit maakt vooraf uitgewerkt beleid meestal overbodig!'

In de gemeente Almere wordt geëxperimenteerd met een werkwijze waarbij inwoners mee bepalen wie de belangrijkste partners zijn in een vraagstuk. Jet van den Biggelaar vertelt: 'We focussen als beleidsmakers te veel zelf op de inhoud. Vandaaruit denken we na over de stakeholders. Maar ook dat moet met de bewoners! Gewoon gaan vragen: voor wie is dit belangrijk?'

\section{Essentieel: duidelijke spelregels en glasheldere communicatie}

In het onderzoek vonden we twee belangrijke factoren voor goede samenwerking tussen kwetsbare inwoners en gemeente: het gebruik van begrijpelijke taal en het duidelijk afspreken van de spelregels. Zo ontstaat voor alle betrokken helderheid, ook over ieders rol in een beleidsproces. Vanessa Duterloo geeft aan: 'In alle contacten die ik heb - met collega's, wethouder en inwoners - is dit de kern. Anders ontstaat wantrouwen of leidt het contact nergens toe. Je moet steeds uitleggen: waarom doe ik wat ik doe?'

Ook in Almere vindt men die helderheid en rolneming belangrijk. 'Je werkt als beleidsadviseur wel vanuit die systeemwereld, maar gedraagt je als in de leefwereld. Dan kom je in een andere dimensie terecht', zo geeft Jet van den Biggelaar aan, 'Ondertussen schrijf ik nog steeds notities, doe literatuuronderzoek, maar: faciliterend!' Martijn Kole zegt daarover: 'Dan gaan inwoners ook anders kijken naar zichzelf en naar de overheid. Zo worden mensen actor, in plaats van leidend voorwerp. Dat leidt tot een duurzamer verhaal. Omdat je het verhaal samen maakt.'

\section{Een (leef)wereld te winnen}

Het onderzoek maakt duidelijk dat er een wereld te winnen is in het samen optrekken met - vooral kwetsbare - inwoners. Daar zijn meer verschillende vormen van samenwerking, goede spelregels en communicatie voor nodig. Het is aan gemeenten om dit structureel onderdeel te maken van het Wmo-beleidsproces. Pas dan doet beleid zijn werk als instrument om individuele en collectieve vraagstukken aan te pakken.

\section{Literatuur}

1. Raad voor het Openbaar Bestuur. Loslaten in vertrouwen. Naar een nieuwe verhouding tussen overheid, markt én samenleving. Den Haag: ROB;2012.

2. Verbeek K, Werfhorst KJ van de, Salome L, et al. Beleidsparticipatie in de Wmo 2015. Een kwalitatief onderzoek naar ervaringen in delokale praktijk. Den Haag: BMC; 2018. 